\title{
Mannose-Binding Lectin: A Potential Therapeutic Candidate against Candida Infection
}

\author{
Noha M. Hammad (D), ${ }^{1}$ Nissreen E. El Badawy, ${ }^{1}$ Hamed A. Ghramh, ${ }^{2,3}$ and Laila M. Al Kady ${ }^{1}$ \\ ${ }^{1}$ Department of Medical Microbiology and Immunology, Faculty of Medicine, Zagazig University, Zagazig, Egypt \\ ${ }^{2}$ Research Center for Advanced Materials Science (RCAMS), King Khalid University, P.O. Box 9004, Abha 61413, Saudi Arabia \\ ${ }^{3}$ Department of Biology, Faculty of Science, King Khalid University, P.O. Box 9004, Abha 61413, Saudi Arabia
}

Correspondence should be addressed to Noha M. Hammad; nmhammad@medicine.zu.edu.eg

Received 8 November 2017; Accepted 15 March 2018; Published 2 May 2018

Academic Editor: Mohamed E. Osman

Copyright (C) 2018 Noha M. Hammad et al. This is an open access article distributed under the Creative Commons Attribution License, which permits unrestricted use, distribution, and reproduction in any medium, provided the original work is properly cited.

\begin{abstract}
Mannose-binding lectin (MBL) is one of the key players in the innate immune system. It has the ability to identify a broad range of pathogens based on recognition of carbohydrate repeats displayed on microbial surfaces. Since mannans make about $40 \%$ of the total polysaccharide content of cell wall of Candida species (spp.) and MBL is capable of high-affinity binding to the mannan fraction of their cell wall component, this study has investigated the direct influence of MBL on Candida in vitro. Candida (C.) albicans and C. glabrata were in vitro exposed to different doses of recombinant human MBL for various time points to assess MBL influence on the production of hyphae and on the yeast forms. Moreover, the direct effect of MBL on the growth of $C$. albicans was measured by a cell proliferation assay. MBL induced agglutination of yeast forms as well as hyphal forms of Candida spp. and significantly reduced proliferation of $C$. albicans in vitro. MBL can be used as a potential antifungal candidate against Candida infection.
\end{abstract}

\section{Introduction}

Mannose-binding lectin (MBL), synthesized in the liver, is a member of a family of proteins called collectins, which is composed of collagenous domains linked to lectin domains. MBL is a large macromolecule that has a bouquet-like structure. The polypeptide chain of secreted MBL is 228 amino-acid long, not including the 20-residue signal peptide. The basic structural subunit of MBL is a homotrimer of MBL polypeptides, twisted in a triple helix. Each single polypeptide chain has four domains: (1) a 21-amino-acid N-terminal cysteine-rich (containing 3 cysteines) region involved in oligomerization by the formation of intra- and intersubunit disulphide bonds, (2) a 59-amino-acid collagen-like domain consisting of 20 tandem repeats of Glycine-Xaa-Yaa, where Xaa-Yaa indicate any amino acid (except repeat 8 , which consists of only Glycine-Glutamine) that account for the long stalk of the molecule, (3) a 30-amino-acid $\alpha$-helical, hydrophobic coiled-coil neck domain, which is crucial for initiating the oligomerization, and (4) a 188-amino-acid
C-terminal carbohydrate recognition domain $[1,2]$. Binding of MBL to pathogenic organisms leads to a change in the conformation of MBL multimer with subsequent activation of MBL-associated serine proteases (MASPs) and eventually initiation of complement lectin pathway [3].

Over the past four decades, many functions of MBL have been revealed. It is clear that MBL plays roles in complement activation, promotion of complement-independent opsonophagocytosis, modulation of inflammation, and recognition of altered self-structures and apoptotic cell clearance [4]. Low concentration of $\mathrm{MBL}$ is associated with increased susceptibility to infections [5].

The cell wall of Candida species (spp.) contains mannoproteins that display mannan in a variety of linkages. The mannan fraction of the cell wall is important for adhesion, cell wall integrity, and immune recognition and comprises up to $40 \%$ of the cell wall dry weight [6-8]. All of the major cell wall carbohydrate components of fungal walls serve as pathogenassociated molecular patterns, which are recognized by the innate immune system through pattern recognition receptors 
on the surface of immune effector cells [9]. Toll-like receptors and C-type lectin receptors, which are pattern recognition receptors, recognize molecular patterns on Candida cell wall, resulting in phagocytosis and killing of the invading fungus [10]. One of the C-type lectin receptors is the soluble, opsonic, multimeric MBL. MBL is able to trigger the complement cascade by recognizing and binding to carbohydrate moieties on the surface of microorganisms in general [11]. Besides, MBL binds with high-affinity to Candida spp. [12].

Different Candida spp., C. albicans and C. dubliniensis, are associated with generation of hyphae. Hypha plays vital role in tissue invasion. Morphogenesis observed in C. albicans is induced by variations in temperature and $\mathrm{pH}$ and presence of serum [13]. Accordingly, most of pathogenicity of C. albicans owes to this transition [14]. On the contrary, under most conditions, C. glabrata exists only as yeast cells [15].

The aim of this study is to assess the in vitro capacity of MBL against yeast cells of C. albicans and C. glabrata as well as hyphal forms of C. albicans.

\section{Materials and Methods}

This study was conducted at Immunology Research Laboratory in Microbiology and Immunology Department, Faculty of Medicine, Zagazig University. This study was carried out in the period of July 2016 to August 2017.

2.1. Ethical Approval. This study was approved by the institutional review board, Faculty of Medicine, Zagazig University, Zagazig, Egypt.

Candida Species. Candida spp. were isolated from vaginal cultures of patients suffering from recurrent vulvovaginal candidiasis and presumptively identified by subculture on chromogenic agar medium (CHROMagar ${ }^{\mathrm{TM}}$ Candida; Paris, France). Cultures were examined under light microscope to show the budding yeast cells with or without pseudohyphae, blastospores, and germ tubes $[6,16]$. In addition, biochemical tests were studied using $\mathrm{Hi}$-Candida ${ }^{\mathrm{TM}}$ API identification kit (Biomereux, France). The isolated spp., Candida. (C.) albicans and C. glabrata, were preserved on deep SDA and stored at $4^{\circ} \mathrm{C}$ for subsequent in vitro experiments.

Candida spp. maintained on deep SDA were allowed to grow overnight in brain-heart infusion broth (Brain-Heart Infusion; Oxoid, $U K$ ) at $37^{\circ} \mathrm{C}$ before use. These conditions allow Candida to grow as a $>95 \%$ pure yeast phase population [17]. Immediately before each experiment, Candida spp., harvested by centrifugation, were washed 3 times with phosphate buffer saline (PBS) (phosphate buffer saline 10x; Electron Microscopy Science, USA) and resuspended to the appropriate concentration in PBS containing $1 \mathrm{mmol} / \mathrm{L} \mathrm{CaCl}_{2}$ and $0.5 \mathrm{mmol} / \mathrm{L} \mathrm{MgCl}_{2}\left(\mathrm{PBS}^{++}\right)$. Experiments were done in duplicate and repeated at least three times.

2.2. Influence of $M B L$ on Hyphae Production and on Yeast Forms. Candida spp. $\left(1 \times 10^{6}\right.$ cells/mL counted by hemocytometer) was incubated with MBL (Recombinant Human $M B L, R \nLeftarrow D$ Systems, Minneapolis, USA) in $100 \mu \mathrm{L}$ of $\mathrm{PBS}^{++}$, with and without $10 \%$ heat-inactivated fetal bovine serum (FBS) (Fetal Bovine Serum; Sigma-Aldrich) for C. albicans and with only $10 \%$ heat-inactivated FBS for C. glabrata, in 96-well microtiter plate at $37^{\circ} \mathrm{C}$ in $5 \% \mathrm{CO}_{2}$ atmosphere (Heraeus Hera cell).

Culturing at $37^{\circ} \mathrm{C}\left(5 \% \mathrm{CO}_{2}\right)$ in serum-rich medium stimulated C. albicans yeasts to germinate. The light microscopic analysis was used to assess MBL influence on yeast cells and on hyphae production. Human recombinant MBL was supplied lyophilized $(50 \mu \mathrm{g})$. It was reconstituted according to manufacturer's company protocol at a concentration of $100 \mu \mathrm{g} / \mathrm{mL}$ with $0.5 \mathrm{~mL}$ sterile PBS. To determine the timedependent factor for MBL influence, Candida yeast cells were incubated with $\mathrm{MBL}$ for various time points $(30 \mathrm{~min}, 1 \mathrm{~h}$, and $3 \mathrm{~h}$ ). Besides, to determine the dose-dependent factor for MBL, Candida yeasts were incubated with various doses of $\operatorname{MBL}(0,5$, and $10 \mu \mathrm{g} / \mathrm{mL})$, since the average normal human MBL serum level is around $5 \mu \mathrm{g} / \mathrm{mL}[17,18]$.

2.3. Influence of $M B L$ on the Growth of Candida albicans. Freshly grown $C$. albicans yeasts $\left(2 \times 10^{7}\right.$ cells $\left./ \mathrm{mL}\right)$ were incubated with $\mathrm{MBL}$ in a final volume of $100 \mu \mathrm{L}$ of $\mathrm{PBS}^{++}$ in Eppendorf tubes at $37^{\circ} \mathrm{C}$ in $5 \% \mathrm{CO}_{2}$ atmosphere. To determine the time-dependent factor for $\mathrm{MBL}$ influence on C. albicans growth, cells were exposed to MBL for various time points ( $15 \mathrm{~min}$ and $30 \mathrm{~min}$ ). Besides, to determine the dose-dependent factor for $\mathrm{MBL}, C$. albicans yeasts were exposed to various doses of $\mathrm{MBL}(0,5$, and $10 \mu \mathrm{g} / \mathrm{mL})$ [17].

2.3.1. Assessment of Candida albicans Growth. The yeast cells were washed with $1 \mathrm{~mL}$ of PBS followed by resuspension in RPMI (Roswell Park Memorial Institute) medium (RPMI1640; Sigma-Aldrich) at $1 \times 10^{6}$ cells $/ \mathrm{mL}$. A final volume of $100 \mu \mathrm{L}$ was transferred to a 96-well microtiter plate and incubated at $37^{\circ} \mathrm{C}$ in $5 \% \mathrm{CO}_{2}$ atmosphere for 3 and $6 \mathrm{~h}$. Wells containing RPMI medium alone and those containing $1 \times$ $10^{6}$ cells $/ \mathrm{mL}$ without previous exposure to MBL served as negative and positive control, respectively [17].

By using XTT-based cell proliferation assay (XTT assay; Sigma-Aldrich), the growth of C. albicans was evaluated after 3 and $6 \mathrm{~h}$ of incubation. The XTT-based assay is a spectrophotometric method for estimating cell number based on the mitochondrial dehydrogenase activity in living cells. The key component is the sodium salt of XTT (2,3-bis[2-methoxy-4nitro-5-sulfophenyl]-2H-tetrazolium-5-carboxyanilide inner salt). The mitochondrial dehydrogenases of viable cells reduce the tetrazolium ring of XTT, yielding an orange formazan derivative, which is water soluble. The absorbance of the resulting orange solution is measured spectrophotometrically [19]. XTT kit was supplied lyophilized (5 mg). It was reconstituted according to manufacturer's company protocol at a concentration of $1 \mathrm{mg} / \mathrm{mL}$ with $5 \mathrm{~mL}$ of sterile PBS. Warming the solution in a $56^{\circ} \mathrm{C}$ water bath helped to dissolve the dye. $20 \mu \mathrm{L}$ of the XTT solution was added to each well. The microtiter plates were then incubated in the dark at $37^{\circ} \mathrm{C}$ in $5 \% \mathrm{CO}_{2}$ atmosphere for $2 \mathrm{~h}$. A colorimetric change was then measured at a wavelength of $450 \mathrm{~nm}$ by using ELISA reader (Stat Fax 303 Plus). 
2.4. Statistical Analysis. Quantitative data were represented as mean value \pm 1 standard deviation (SD). $F$ test was used for calculation of the mean difference between different groups. Least significance difference (LSD) test was used for multiple comparisons. Paired $t$-test was used for calculation of the mean difference within the same group at different time points. All analyses were 2-tailed. Results were considered statistically significant when $p$ (probability) values were equal to or less than 0.05 at confidence interval (CI) 95\%. All analyses were performed using Statistical Package for the Social Sciences software (SPSS version 20, Inc., Chicago, IL, USA.).

\section{Results}

3.1. Influence of $M B L$ on Hyphae Production and on Yeast Forms. Light microscopic analysis revealed that MBL had no influence on the germination of C. albicans yeasts. C. albicans yeasts in the presence or absence of MBL germinated and formed hyphae within $3 \mathrm{~h}$ incubation. However, in the presence of MBL, agglutination of hyphae was observed. Moreover, in the presence of MBL, agglutination was observed when (1) yeast phase of C. albicans was incubated with $10 \%$ FBS, (2) yeast forms of $C$. albicans were incubated without FBS, and (3) yeast forms C. glabrata were incubated with $10 \%$ FBS. When the dose-dependent factor was evaluated, agglutination of both hyphae and yeast cells was markedly observed with $10 \mu \mathrm{g} / \mathrm{mL} \mathrm{MBL}$ compared to $5 \mu \mathrm{g} / \mathrm{mL} \mathrm{MBL}$. When the time-dependent factor was evaluated, agglutination of hyphae markedly increased as more hyphae were induced and elongated over different time points: $30 \mathrm{~min}, 1 \mathrm{~h}$, and $3 \mathrm{~h}$ incubation. Besides, agglutination of yeast cells was markedly increased over different time points, $30 \mathrm{~min}, 1 \mathrm{~h}$, and $3 \mathrm{~h}$ incubation, as shown in Figures 1-4.

3.2. Influence of $M B L$ on the Growth of Candida albicans after $3 \mathrm{~h}$ Incubation. When the direct influence of MBL on the growth of $C$. albicans by XTT assay was estimated after $3 \mathrm{~h}$ incubation period, there was statistically significant reduction in growth when $C$. albicans was exposed to 5 and $10 \mu \mathrm{g} / \mathrm{mL} \mathrm{MBL}$ for $15 \mathrm{~min}$ and to $5 \mu \mathrm{g} / \mathrm{mL} \mathrm{MBL}$ for $30 \mathrm{~min}$ compared to positive control $(\mathrm{MBL}=0 \mu \mathrm{g} / \mathrm{mL})(p=0.013$, $p=0.005$, and $p=0.004$, resp.). However, there was no reduction in growth after exposure to $10 \mu \mathrm{g} / \mathrm{mL} \mathrm{MBL}$ for $30 \mathrm{~min}$ compared to positive control $(p=0.700)$. When the dose-dependent factor was evaluated, there was no statistically significant difference in growth after exposure to 5 and $10 \mu \mathrm{g} / \mathrm{mL}$ MBL for $15 \mathrm{~min}(p=0.631)$. However, after 30 min exposure, there was statistically significant reduction in growth with $5 \mu \mathrm{g} / \mathrm{mL}$ MBL compared to $10 \mu \mathrm{g} / \mathrm{mL} \mathrm{MBL}$ $(p=0.002)$. When the time-dependent factor was evaluated, there was no statistically significant difference in growth between 15 and $30 \mathrm{~min}$ exposure to both 5 and $10 \mu \mathrm{g} / \mathrm{mL} \mathrm{MBL}$ ( $p=0.264$ and $p=0.123$, resp.) as demonstrated by Table 1 and Figure 5.

3.3. Influence of $M B L$ on the Growth of Candida albicans after $6 \mathrm{~h}$ Incubation. When the direct influence of MBL on the growth of $C$. albicans by XTT assay was estimated after $6 \mathrm{~h}$ incubation period, there was statistically significant reduction in growth when $C$. albicans was exposed to 5 and $10 \mu \mathrm{g} / \mathrm{mL} \mathrm{MBL}$ for $15 \mathrm{~min}$ and to $5 \mu \mathrm{g} / \mathrm{mL} \mathrm{MBL}$ for $30 \mathrm{~min}$ compared to positive control $(\mathrm{MBL}=0 \mu \mathrm{g} / \mathrm{mL})(p=0.007$, $p=0.036$ and $p=0.006$, resp.). However, the reduction of growth was not statistically significant when $C$. albicans was exposed to $10 \mu \mathrm{g} / \mathrm{mL} \mathrm{MBL}$ for $30 \mathrm{~min}$ compared to positive control $(p=0.934)$. When the dose-dependent factor was evaluated, there was statistically significant reduction in growth after $30 \mathrm{~min}$ exposure to $5 \mu \mathrm{g} / \mathrm{mL} \mathrm{MBL}$ compared to $10 \mu \mathrm{g} / \mathrm{mL} \mathrm{MBL}$; however, such reduction was not statistically significant after 15 min exposure, $(p=0.007, p=0.346$, resp.). When the time-dependent factor was evaluated, there was no statistically significant difference in growth between 15 and $30 \mathrm{~min}$ exposure to both 5 and $10 \mu \mathrm{g} / \mathrm{mL} \mathrm{MBL}(p=0.922$ and $p=0.198$, resp.) as demonstrated by Table 2 and Figure 5.

\section{Discussion}

For more than a decade, the potential of MBL as a therapeutic agent has been proposed [20]. MBL replacement therapy was previously investigated in patients with recurrent erythema multiform and severe cystic fibrosis via infusion of fresh frozen plasma containing MBL, resulting in clinical improvement of the patients $[21,22]$. In this context, the present study has investigated the direct influence of MBL on C. albicans and C. glabrata in vitro.

This study demonstrates that MBL recognized Candida spp. and induced their agglutination in yeast form as well as upon induction of hyphae. Nevertheless, MBL was unable to inhibit the transition of $C$. albicans from the yeast phase to hyphal phase, since C. glabrata grows strictly in pure yeast form under most conditions [15]. Besides, MBL induced agglutination was both time- and dose-dependent. A possible explanation is that long incubations were associated with more hyphal outgrowth with a subsequent increase in MBLligand expression on the growing hyphae. Similarly, budding of the yeast cells could enhance the chance of MBL-ligand expression.

These findings agree with the study of Lillegard and his colleagues who found that MBL binds extensively to both hyphae and budding yeast cells [8]. Moreover, the previous report of Ip and Lau suggested that steric hindrance by MBL can prevent the spread of the virulent forms of Candida by blocking the receptors. However, Ip and Lau found that MBL induced agglutination only with hyphal forms of C. albicans but not with yeast forms [17].

The present study has reported significant suppression in the growth of $C$. albicans during an incubation period for up to 6 hours. This significant suppression was observed with exposure to $5 \mu \mathrm{g} / \mathrm{mL}$ MBL for 15 and $30 \mathrm{~min}$, while $10 \mu \mathrm{g} / \mathrm{mL}$ MBL induced significant suppression with exposure for $15 \mathrm{~min}$ but not $30 \mathrm{~min}$. MBL induced growth suppression was not time-dependent; however, it was dose-dependent only with $30 \mathrm{~min}$ exposure. The $5 \mu \mathrm{g} / \mathrm{mL} \mathrm{MBL}$ is quite close to the average normal human MBL serum level [18]. Therefore, it seems that $5 \mu \mathrm{g} / \mathrm{mL}$ MBL was optimum and more effective than $10 \mu \mathrm{g} / \mathrm{mL}$ MBL. Moreover, MBL-ligand binding, like any macromolecules, is governed by the dissociation constant, 


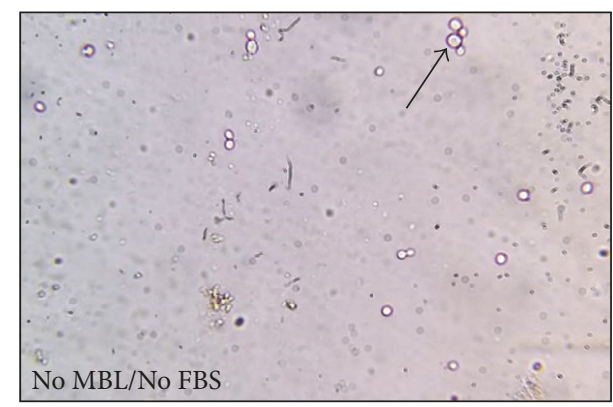

(a)

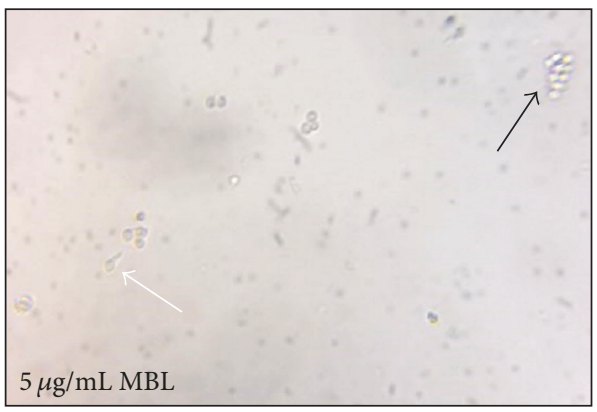

(c)

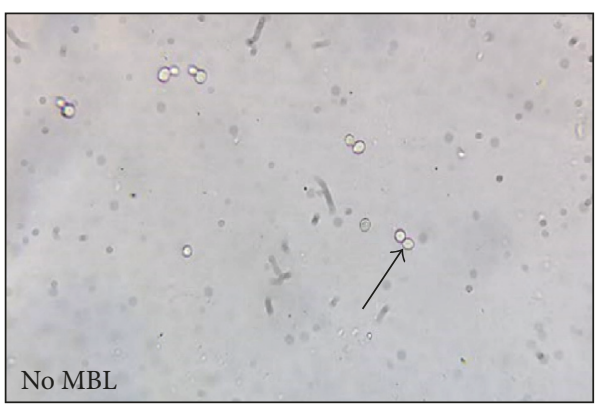

(b)

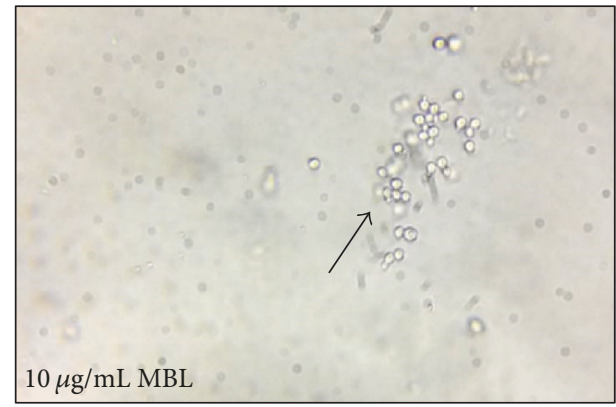

(d)

FIGURE 1: MBL induced agglutination of Candida albicans after 30 min incubation. (a) In absence of MBL and FBS, no agglutination is observed with yeast form of C. albicans (Black arrow). (b) In absence of MBL and presence of $10 \%$ FBS, no agglutination is observed with yeast phase of C. albicans (Black arrow). (c) and (d) In presence of 5 and $10 \mu \mathrm{g} / \mathrm{mL}$ MBL with $10 \% \mathrm{FBS}$, agglutination of yeast phase of C. albicans is started to be observed (Black arrow). Germination of hyphae starts to occur (White arrow).

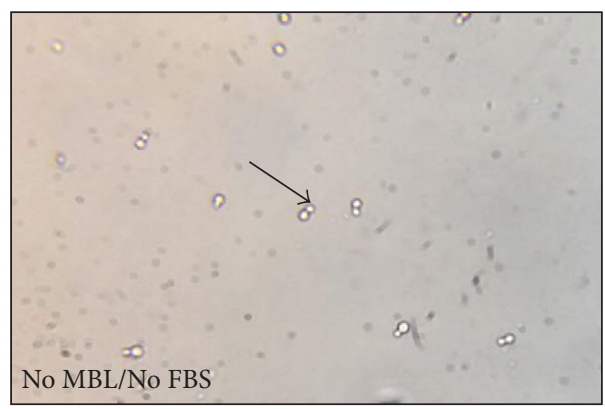

(a)

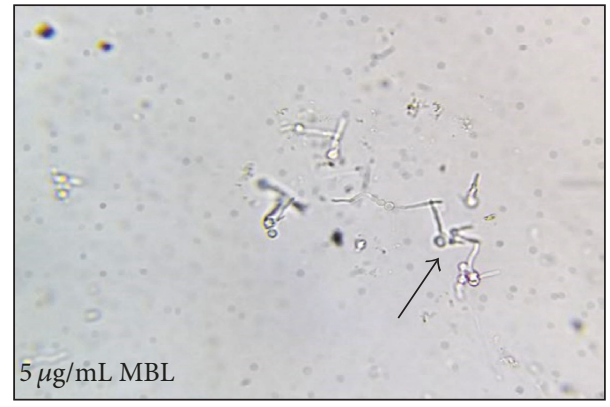

(c)

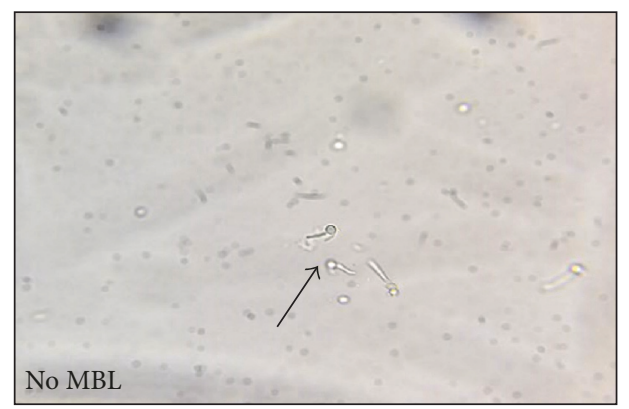

(b)

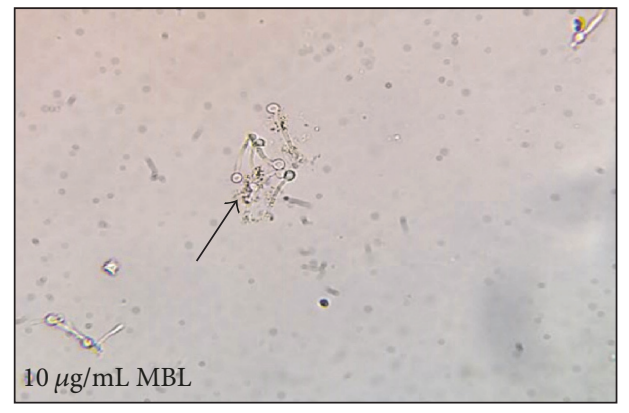

(d)

FIGURE 2: MBL induced agglutination of Candida albicans after $1 \mathrm{~h}$ incubation. (a) In absence of MBL and FBS, no agglutination is observed with yeast form of C. albicans (Black arrow). (b) In absence of MBL and presence of $10 \%$ FBS, no agglutination only germination of hyphae is observed (Black arrow). (c) and (d) In presence of 5 and $10 \mu \mathrm{g} / \mathrm{mL}$ MBL with 10\% FBS, agglutination of germinated hyphae of C. albicans is started to be observed (Black arrow). 


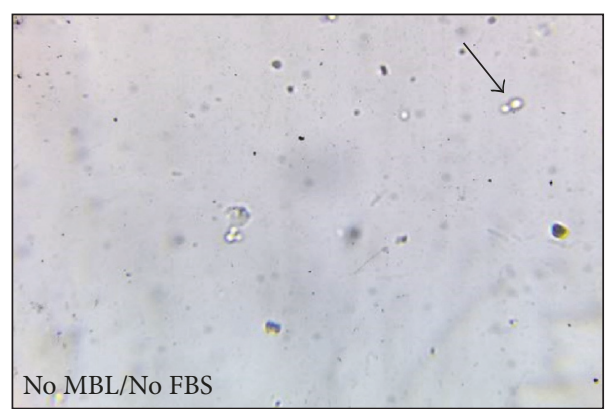

(a)

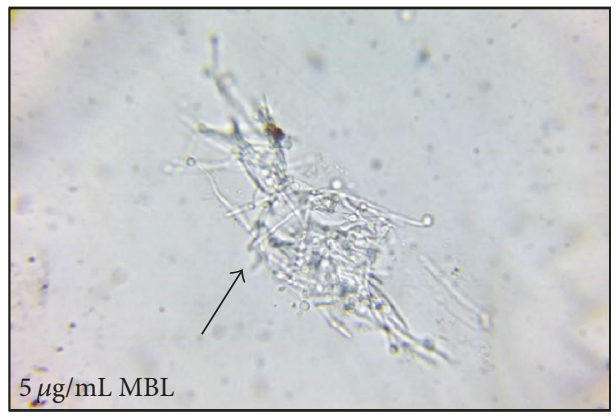

(c)

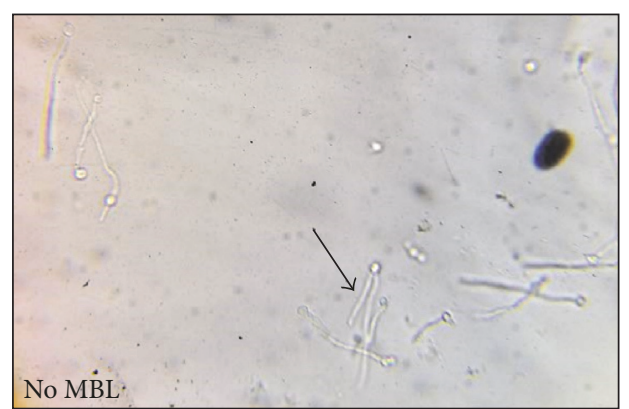

(b)

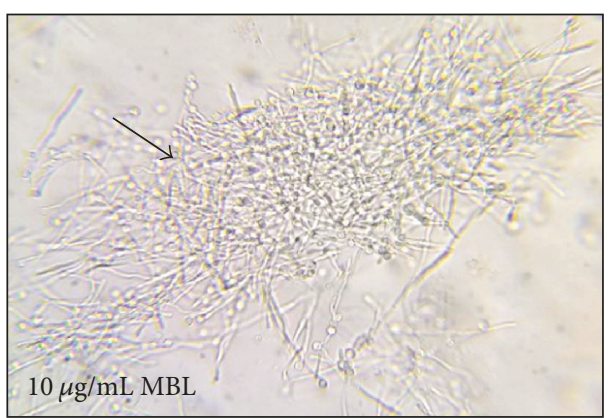

(d)

FIGURE 3: MBL induced agglutination of Candida albicans after $3 \mathrm{~h}$ incubation. (a) In absence of MBL and FBS, no agglutination is observed with yeast form of $C$. albicans (Black arrow). (b) In absence of MBL and presence of $10 \%$ FBS, no agglutination only elongation of hyphae is observed (Black arrow). (c) and (d) In presence of 5 and $10 \mu \mathrm{g} / \mathrm{mL}$ MBL with 10\% FBS, increased agglutination and elongation of hyphae of C. albicans are observed (Black arrow) The effect is more potentiated with $10 \mu \mathrm{g} / \mathrm{mL} \mathrm{MBL}$ when compared to $5 \mu \mathrm{g} / \mathrm{mL}$.

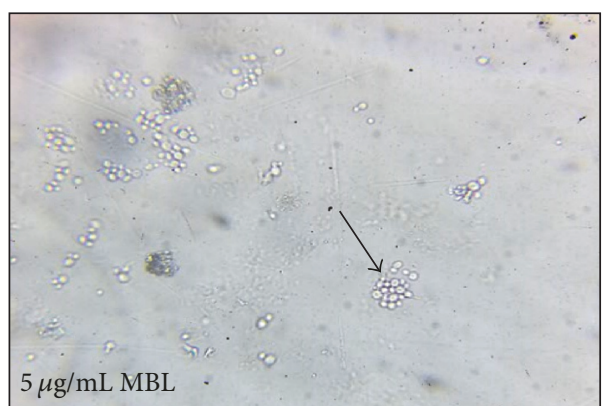

(a)

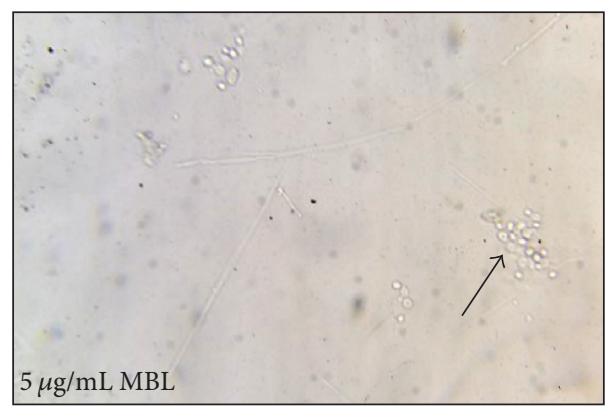

(c)

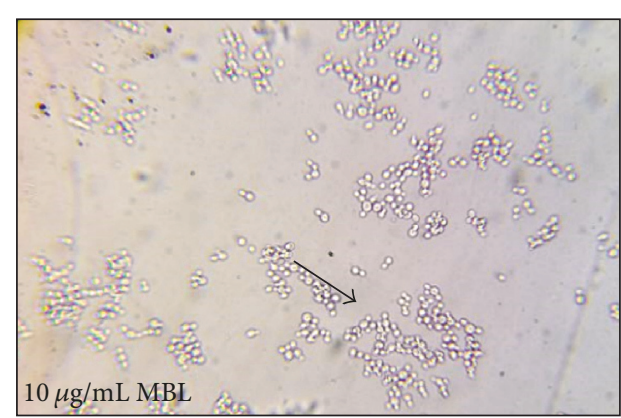

(b)

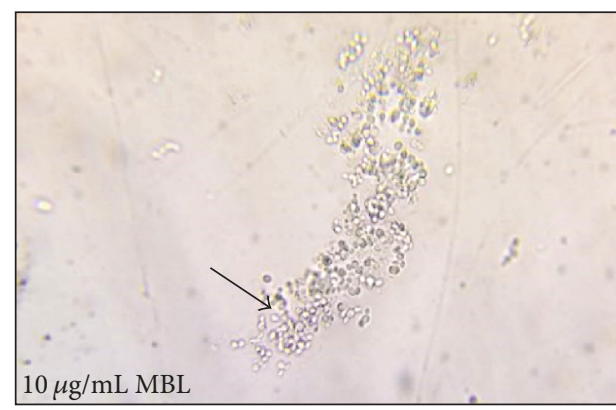

(d)

FiguRE 4: MBL induced agglutination of yeast cells of Candida species after $3 \mathrm{~h}$ incubation. (a) and (b) In presence of $5 \mathrm{and} 10 \mu \mathrm{g} / \mathrm{mL} \mathrm{MBL}$ without FBS, agglutination of C. albicans is observed. (c) and (d) The same effect of 5 and $10 \mu \mathrm{g} / \mathrm{mL} \mathrm{MBL}$ is also observed with C. glabrata. The effect is more potentiated with $10 \mu \mathrm{g} / \mathrm{mL}$ MBL (Black arrows) when compared to $5 \mu \mathrm{g} / \mathrm{mL}$ MBL (Black arrows). 
TABLE 1: Direct influence of MBL on the growth of Candida albicans measured by XTT assay after $3 \mathrm{~h}$ incubation period.

\begin{tabular}{|c|c|c|c|c|c|c|}
\hline MBL concentration & $0 \mu \mathrm{g} / \mathrm{mL}$ & $5 \mu \mathrm{g} / \mathrm{mL}$ & $10 \mu \mathrm{g} / \mathrm{mL}$ & Test of significance & $p$ value & $\begin{array}{c}\text { LSD } \\
p \text { value }\end{array}$ \\
\hline \multicolumn{7}{|c|}{$15 \mathrm{~min}$ exposure to $\mathrm{MBL}$} \\
\hline $\begin{array}{l}\text { Absorbance } \\
\text { Mean } \pm \text { SD }\end{array}$ & $1.95 \pm 0.11$ & $1.37 \pm 0.29$ & $1.28 \pm 0.38$ & $\begin{array}{l}\text { F test } \\
21.398\end{array}$ & $<0.001^{*}$ & $\begin{array}{l}0.013^{* * 1} \\
0.005^{* * 2} \\
0.631^{* * 3}\end{array}$ \\
\hline \multicolumn{7}{|c|}{$30 \mathrm{~min}$ exposure to $\mathrm{MBL}$} \\
\hline $\begin{array}{l}\text { Absorbance } \\
\text { Mean } \pm \text { SD }\end{array}$ & $1.71 \pm 0.23$ & $1.10 \pm 0.33$ & $1.78 \pm 0.15$ & $\begin{array}{l}\text { F test } \\
\mathbf{2 8 . 5 8 3}\end{array}$ & $<0.001^{*}$ & $\begin{array}{l}0.004^{* * 1} \\
0.700^{* * 2} \\
0.002^{* * 3}\end{array}$ \\
\hline \multicolumn{7}{|c|}{$\begin{array}{l}\text { Between different MBL exposure } \\
\text { time points ( } 15 \text { and } 30 \mathrm{~min})\end{array}$} \\
\hline \multirow{2}{*}{ Test of significance } & & \multicolumn{2}{|c|}{ Paired $t$-test } & & & \\
\hline & & $\mathrm{t}=1.370$ & $t=-2.128$ & & & \\
\hline$p$ value & & $0.264^{* * 4}$ & $\mathbf{0 . 1 2 3} 3^{* * 5}$ & & & \\
\hline
\end{tabular}

TABLE 2: Direct influence of MBL on the growth of Candida albicans measured by XTT assay after $6 \mathrm{~h}$ incubation period.

\begin{tabular}{|c|c|c|c|c|c|c|}
\hline MBL concentration & $0 \mu \mathrm{g} / \mathrm{mL}$ & $5 \mu \mathrm{g} / \mathrm{mL}$ & $10 \mu \mathrm{g} / \mathrm{mL}$ & Test of significance & $p$ value & $\begin{array}{c}\text { LSD } \\
p \text { value }\end{array}$ \\
\hline \multicolumn{7}{|c|}{15 min exposure to MBL } \\
\hline $\begin{array}{l}\text { Absorbance } \\
\text { Mean } \pm \text { SD }\end{array}$ & $2.51 \pm 0.04$ & $1.59 \pm 0.37$ & $1.86 \pm 0.59$ & $\begin{array}{l}\text { F test } \\
\mathbf{1 8 . 1 9 7}\end{array}$ & $<0.001^{*}$ & $\begin{array}{l}0.007^{* * 1} \\
0.036^{* * 2} \\
0.346^{* * 3}\end{array}$ \\
\hline \multicolumn{7}{|c|}{30 min exposure to $\mathrm{MBL}$} \\
\hline $\begin{array}{l}\text { Absorbance } \\
\text { Mean } \pm \text { SD }\end{array}$ & $2.29 \pm 0.17$ & $1.55 \pm 0.47$ & $2.27 \pm 0.23$ & $\begin{array}{l}\text { F test } \\
\mathbf{2 9 . 0 7 6}\end{array}$ & $<0.001^{*}$ & $\begin{array}{l}0.006^{* * 1} \\
0.934^{* * 2} \\
0.007^{* * 3}\end{array}$ \\
\hline \multicolumn{7}{|c|}{$\begin{array}{l}\text { Between different MBL exposure } \\
\text { time points ( } 15 \text { and } 30 \mathrm{~min})\end{array}$} \\
\hline \multirow{2}{*}{ Test of significance } & & \multicolumn{2}{|c|}{ Paired $t$-test } & & & \\
\hline & & $\mathrm{t}=0.106$ & $t=-1.647$ & & & \\
\hline$p$ value & & $0.922^{* * 4}$ & $0.198^{* * 5}$ & & & \\
\hline
\end{tabular}

and the affinity of binding is much influenced by hydrogen bonding, electrostatic interaction, and hydrophobicity of the cell surface clustering of the ligands. In addition, multivalent binding results in clustering of the receptors [23].

This work agrees with the study of Ip and Lau. They observed that MBL induced a significant reduction in the growth of $C$. albicans when added to heat-inactivated MBLdeficient serum, a situation in which complement activation would not occur. This suggested that MBL possesses an intrinsic mechanism through which it inhibits the fungal growth. However, the maximum inhibitory effect was observed with unheated MBL-deficient serum demonstrating the importance of lectin pathway in inhibiting the growth of C. albicans [17]. When mice, treated with intravenous $\mathrm{MBL}$, were challenged with C. albicans, prolonged survival of mice was significantly observed [8]. It is also possible that MBL induced agglutination of yeast cells could limit the availability of the nutrients to them resulting in growth inhibition. Consistently, intravaginal administration of recombinant human MBL coupled to itraconazole in $M B L$ gene knockout mice with $C$. albicans vaginitis resulted in 3-fold clearance of yeast compared to itraconazole alone [24]. Although its clinical efficacy has not been clearly evidenced, no side effects of exogenous MBL administration were identified, and some clinical benefits were apparent [25]. Therefore, the present study strongly recommends the potential usefulness of this approach and its extension to large-scale randomized clinical trials; hence, this would provide a solid evidence concerning 


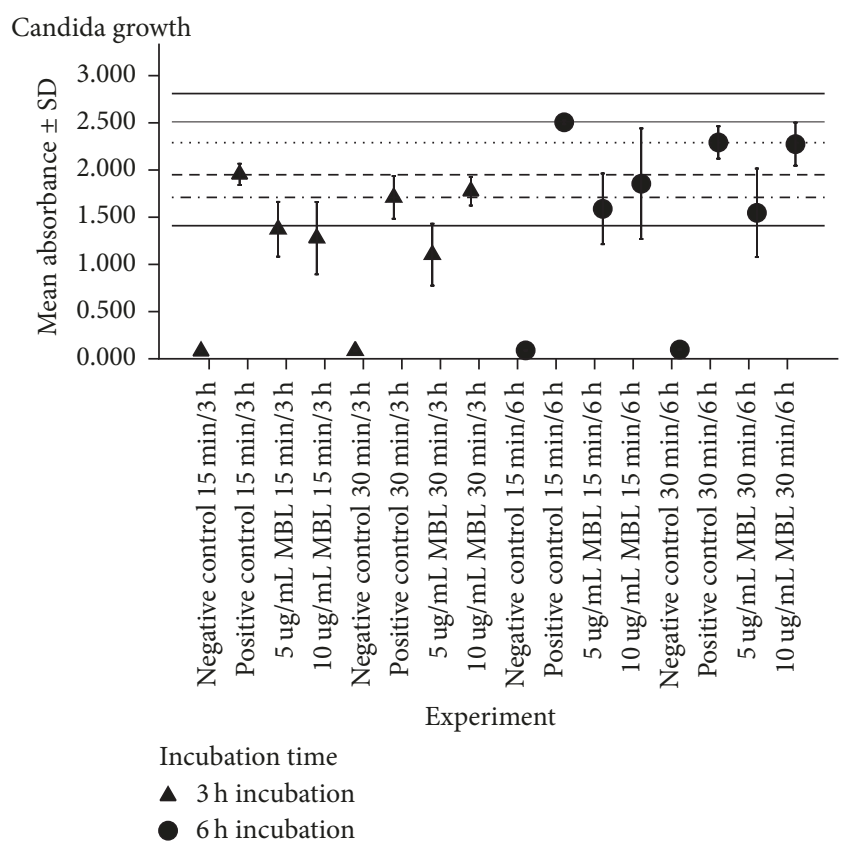

Figure 5: Summary of direct influence of MBL on Candida albicans growth in vitro. Dashed line (- - - - -) represents mean absorbance of positive control $(1.95 \pm 0.11)$ after $15 \mathrm{~min}$ exposure to $0 \mu \mathrm{g} / \mathrm{mL}$ MBL and $3 \mathrm{~h}$ incubation period. Dot-dash line $(\cdot \cdot \cdot \cdot \cdot-\cdot \cdot \cdot-)$ represents mean absorbance of positive control $(1.71 \pm 0.23)$ after $30 \mathrm{~min}$ exposure to $0 \mu \mathrm{g} / \mathrm{mL} \mathrm{MBL}$ and $3 \mathrm{~h}$ incubation period. Continuous line $(-)$ represents mean absorbance of positive control $(2.51 \pm 0.04)$ after $15 \mathrm{~min}$ exposure to $0 \mu \mathrm{g} / \mathrm{mL} \mathrm{MBL}$ and $6 \mathrm{~h}$ incubation period. Dotted line $(\ldots \ldots \ldots)$ represents mean absorbance of positive control $(2.29 \pm 0.17)$ after $30 \mathrm{~min}$ exposure to $0 \mu \mathrm{g} / \mathrm{mL} \mathrm{MBL}$ and $6 \mathrm{~h}$ incubation period. Data are plotted as mean absorbance \pm SD of 3 separate experiments. Absorbance is at $450 \mathrm{~nm}$.

the physiological significance of $\mathrm{MBL}$ against resistant or recurrent Candida infections, particularly in MBL-deficient subjects.

\section{Conclusion}

Recombinant human MBL can induce agglutination of $C$. albicans and C. glabrata yeast cells and hyphal forms of $C$. albicans. Moreover, it can significantly reduce the growth of C. albicans in vitro. These effects could nominate MBL as a potential therapeutic agent against Candida infection.

\section{Conflicts of Interest}

The authors declare that there are no conflicts of interest regarding the publication of this article.

\section{Acknowledgments}

The authors would like to express their gratitude to Research Center of Advanced Materials, King Khalid University, Saudi Arabia, for support. Also, the authors would like to acknowledge Scientific and Medical Research Center of Zagazig University "ZSMRC”, Faculty of Medicine, for support.

\section{References}

[1] P. Garred, F. Larsen, J. Seyfarth, R. Fujita, and H. O. Madsen, "Mannose-binding lectin and its genetic variants," Genes \& Immunity, vol. 7, no. 2, pp. 85-94, 2006.

[2] J. S. Presanis, M. Kojima, and R. B. Sim, "Biochemistry and genetics of mannan-binding lectin (MBL)," Biochemical Society Transactions, vol. 31, no. 4, pp. 748-752, 2003.

[3] D. L. Worthley, P. G. Bardy, D. L. Gordon, and C. G. Mullighan, "Mannose-binding lectin and maladies of the bowel and liver," World Journal of Gastroenterology, vol. 12, no. 40, pp. 6420$6428,2006$.

[4] Z.-Y. Wang, Z.-R. Sun, and L.-M. Zhang, "The relationship between serum mannose-binding lectin levels and acute ischemic stroke risk," Neurochemical Research, vol. 39, no. 2, pp. 248-253, 2014.

[5] E. Kiseljaković, S. Hasić, A. Valjevac et al., "Association of Mannose-Binding Lectin $2(\mathrm{mbl} 2)$ gene heterogeneity and its serum concentration with osteoporosis in postmenopausal women," Bosnian Journal of Basic Medical Sciences, vol. 14, no. 1, pp. 9-25, 2014.

[6] T. I. El-Sayed, D. Atef, M. Amer, A. Mahdy, and G. Enan, "Molecular characterization and inhibition by natural agents of multidrug resistant Candida strains causing vaginal candidiasis," Research Journal of Medical Sciences, vol. 9, no. 1, pp. 1-7, 2015.

[7] G. Enan, T. I. EL-Sayed, D. Atef, M. Amer, and A. Mahdy, "Causal organisms, pathogenicity, laboratory diagnosis and treatment of candidiasis," Research Journal of Applied Sciences , vol. 10, no. 4, pp. 115-135, 2015.

[8] J. B. Lillegard, R. B. Sim, P. Thorkildson, M. A. Gates, and T. R. Kozel, "Recognition of Candida albicans by mannan-binding lectin in vitro and in vivo," The Journal of Infectious Diseases, vol. 193, no. 11, pp. 1589-1597, 2006.

[9] R. A. Hall, S. Bates, M. D. Lenardon et al., "The Mnn2 mannosyltransferase family modulates mannoprotein fibril length, immune recognition and virulence of Candida albicans," PLoS Pathogens, vol. 9, no. 4, Article ID e1003276, 2013.

[10] S. P. Smeekens, F. L. van de Veerdonk, B. J. Kullberg, and M. G. Netea, "Genetic susceptibility to Candida infections," EMBO Molecular Medicine, vol. 5, no. 6, pp. 805-813, 2013.

[11] B. Nedovic, B. Posteraro, E. Leoncini et al., "Mannose-binding lectin codon 54 gene polymorphism and vulvovaginal candidiasis: A systematic review and meta-analysis," BioMed Research International, vol. 2014, Article ID 738298, 7 pages, 2014.

[12] N. Brouwer, K. M. Dolman, M. van Houdt, M. Sta, D. Roos, and T. W. Kuijpers, "Mannose-binding lectin (MBL) facilitates opsonophagocytosis of yeasts but not of bacteria despite MBL binding," The Journal of Immunology, vol. 180, no. 6, pp. 41244132, 2008.

[13] J. F. Fisher, K. Kavanagh, J. D. Sobel, C. A. Kauffman, and C. A. Newman, "Candida urinary tract infection: Pathogenesis," Clinical Infectious Diseases, vol. 52, no. 6, pp. S437-S451, 2011.

[14] A. Cassone, "Vulvovaginal Candida albicans infections: Pathogenesis, immunity and vaccine prospects," BJOG: An International Journal of Obstetrics \& Gynaecology, vol. 122, no. 6, pp. 785-794, 2015.

[15] L. Kasper, K. Seider, and B. Hube, "Intracellular survival of Candida glabrata in macrophages: Immune evasion and persistence," FEMS Yeast Research, vol. 15, no. 5, Article ID fov042, 2015. 
[16] L. J. R. Milne and T. Mackie, Mackie \& McCartney Practical Medical Microbiology, Charchil Livingstone, New York, NY, USA, 14th edition, 1998.

[17] W. K. Ip and Y. L. Lau, "Role of mannose-binding lectin in the innate defense against Candida albicans: enhancement of complement activation, but lack of opsonic function, in phagocytosis by human dendritic cells," The Journal of Infectious Diseases, vol. 190, no. 3, pp. 632-640, 2004.

[18] O. Babula, G. Lazdane, J. Kroica, W. J. Ledger, and S. S. Witkin, "Relation between recurrent vulvovaginal candidiasis, vaginal concentrations of mannose-binding lectin, and a mannosebinding lectin gene polymorphism in latvian women," Clinical Infectious Diseases, vol. 37, no. 5, pp. 733-737, 2003.

[19] N. W. Roehm, G. H. Rodgers, S. M. Hatfield, and A. L. Glasebrook, "An improved colorimetric assay for cell proliferation and viability utilizing the tetrazolium salt XTT," Journal of Immunological Methods, vol. 142, no. 2, pp. 257-265, 1991.

[20] J. A. Summerfield, "Clinical potential of mannose-binding lectin-replacement therapy," Biochemical Society Transactions, vol. 31, no. 4, pp. 770-773, 2003.

[21] H. Valdimarsson, "Infusion of plasma-derived mannan-binding lectin (MBL) into MBL-deficient humans," Biochemical Society Transactions, vol. 31, no. 4, pp. 768-769, 2003.

[22] P. Garred, T. Pressler, S. Lanng et al., "Mannose-binding lectin (MBL) therapy in an MBL-deficient patient with severe cystic fibrosis lung disease," Pediatric Pulmonology, vol. 33, no. 3, pp. 201-207, 2002.

[23] T. K. Lindhorst, Oligosaccharides and Glycoconjugates in Recognition Proesses. Carbohydrate-Modifying Biocatalysts, Pan Stanford Publishing Pte. Ltd., Singapore, 2011.

[24] K. V. Clemons, M. Martinez, M. Axelsen, S. Thiel, and D. A. Stevens, "Efficacy of recombinant human mannose binding lectin alone and in combination with itraconazole against murine Candida albicans vaginitis," Immunological Investigations, vol. 40, no. 6, pp. 553-568, 2011.

[25] G. De Pascale, S. L. Cutuli, M. A. Pennisi, and M. Antonelli, "The role of mannose-binding lectin in severe sepsis and septic shock," Mediators of Inflammation, vol. 2013, Article ID 625803, 8 pages, 2013. 


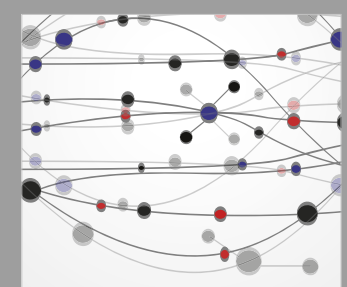

The Scientific World Journal
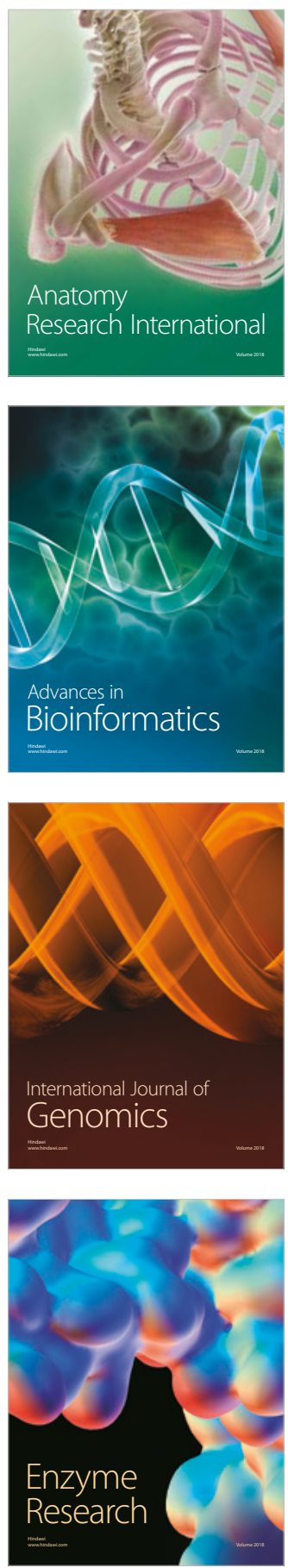
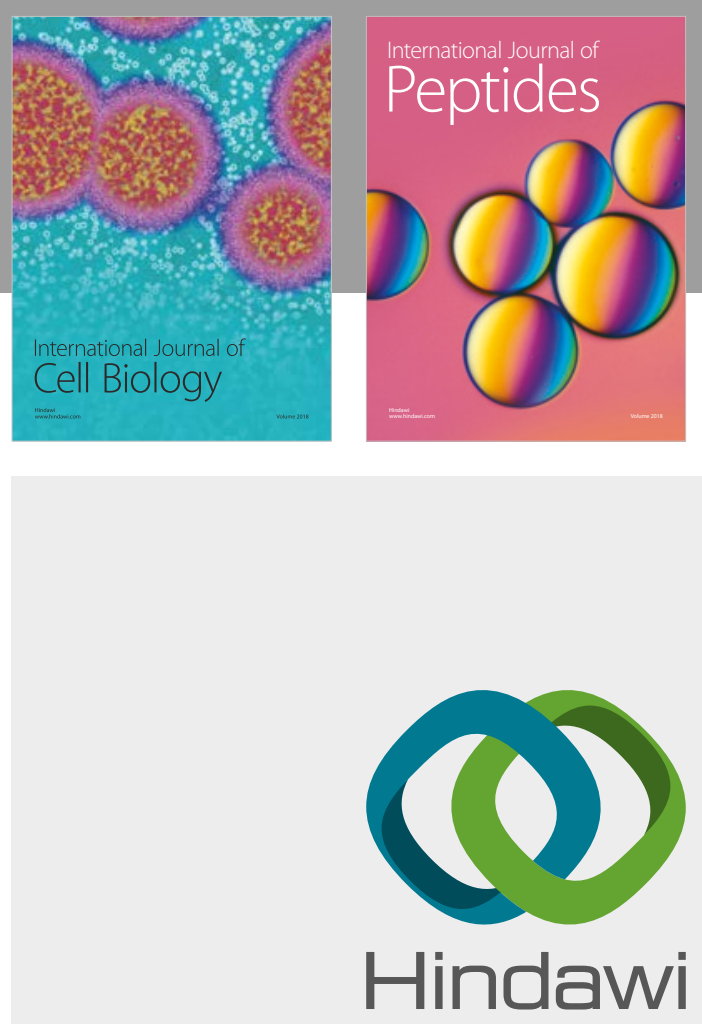

Submit your manuscripts at

www.hindawi.com
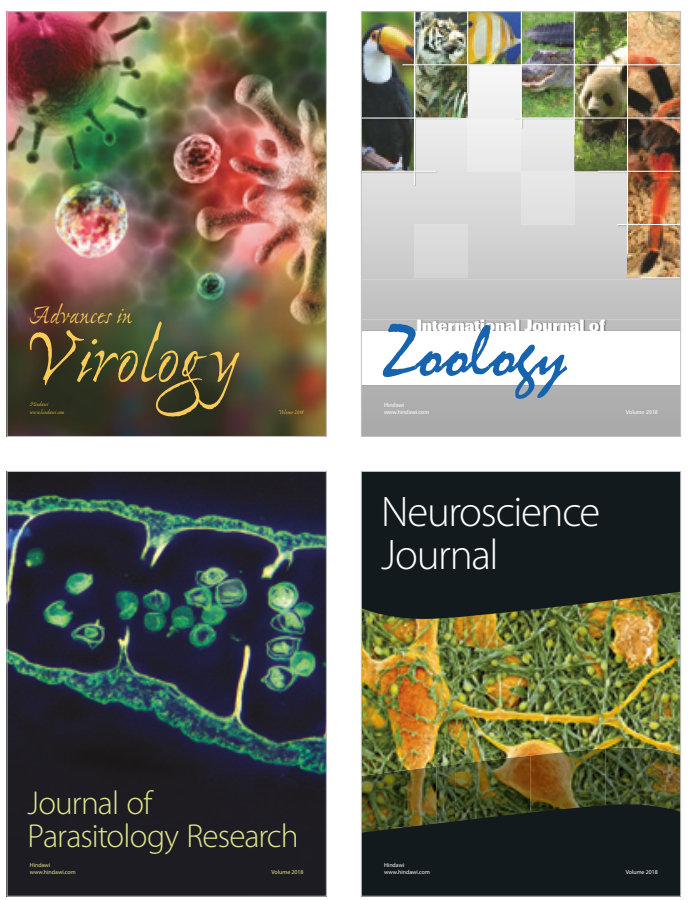
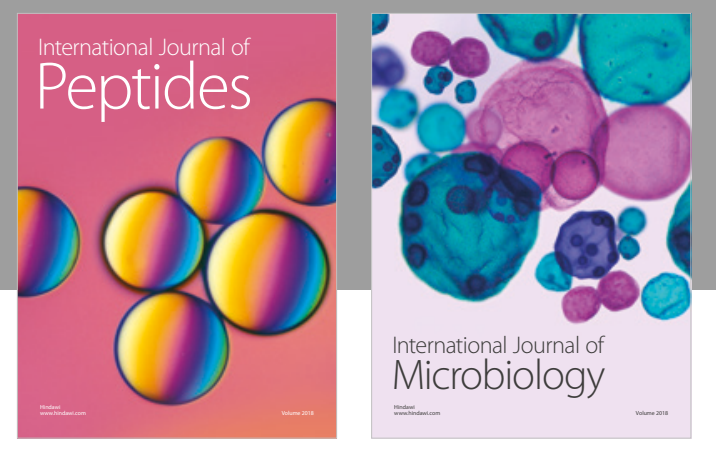

nternational Journal of Microbiology
Journal of
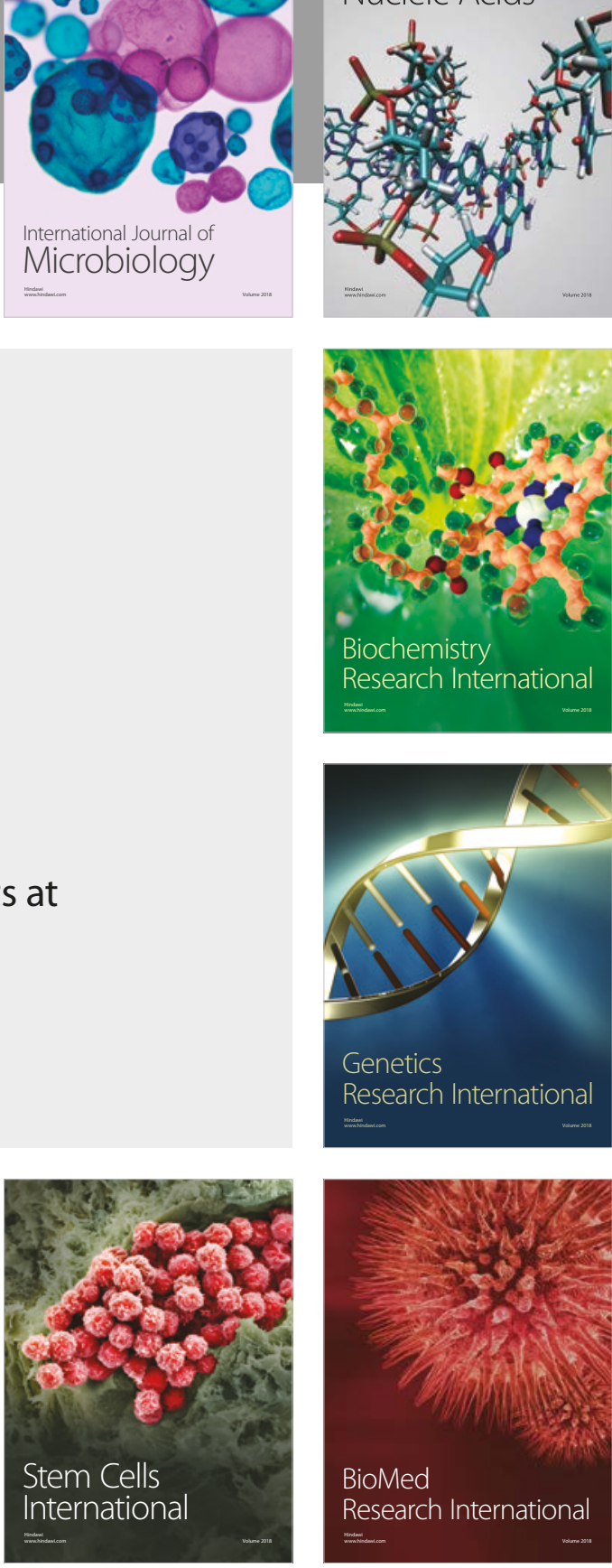
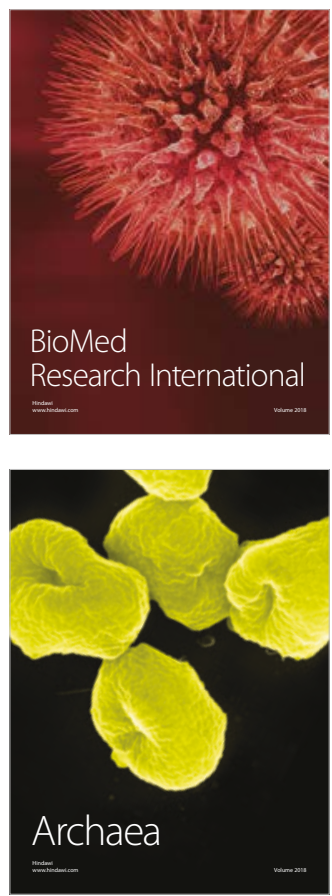